\title{
Effects of ulinastatin and docataxel on breast tumor growth and expression of IL-6, IL-8, and TNF- $\alpha$
}

\author{
Xiaoliang Zhao, Xin Sun, Feng Gao, Jie Luo, Zhijun Sun
}

\begin{abstract}
Objective: This study investigated the effects of Ulinastatin (UTI) and docataxel (Taxotere, TAX) on tumor growth and expression of interleukin-6 (IL-6), interleukin-8 (IL-8), and tumor necrosis factor- $\alpha$ (TNF- $\alpha$ ) in breast cancer.

Methods: MDA-MB-231 human breast carcinoma cells were cultured in vitro and injected into nude mice to establish breast tumor xenografts in vivo. Cultured cells and mice with tumors were randomly divided into four groups for treatment with TAX, UTI, and TAX+UTI. The effects of these drug treatments on cell proliferation and apoptosis was measured using the MTT assay and the Annexin V/propidium iodide (PI) double-staining method, respectively. IL-6, IL-8, and TNF- $\alpha$ expression levels were determined by measuring mRNA transcripts in cultured cells by RT-PCR and cytokine proteins in solid tumors using immunohistochemistry.
\end{abstract}

Results: UTI, TAX, and UTI+TAX inhibited the growth of MDA-MB-231 cells in vitro and tumors in vivo. These two drugs, particularly when used in combination, promote tumor cell apoptosis and down-regulate the expression IL-6, IL-8, and TNF- $\alpha$ cytokines.

Conclusion: Both UTI and TAX inhibited the growth of MDA-MB-231 breast carcinoma cells. UTI enhanced the inhibitory effect of TAX by a mechanism consistent with the down-regulated expression of IL-6, IL-8, and TNF- $\alpha$.

\section{Backgroud}

Along with the increasing incidence of breast cancer tumors, which now account for $18 \%$ of all female tumors, 1.2 million women suffer from breast cancer worldwide. Many important problems pertaining to the oncological details of invasion and metastasis pose significant challenges to scientists.

With the development of new techniques in molecular biology, further exploration into the mechanisms related to the occurrence of breast cancer have become a hotspot in the field of cancer research. The cytokines, which play regulatory roles in disease development have become an important topic for many researchers. IL-6, IL-8, and TNF- $\alpha$ are one group of cytokines produced by mononuclear macrophages and endotheliocytes involved in activating and inducing $\mathrm{T}$ cells, B cells, and natural killer cells to target and phagocytosize

\footnotetext{
* Correspondence: cq_sunzj@sina.com Department of Breast, Pancreas, and Thyroid Surgery; Second Affiliated Hospital of Chongqing Medical University, 74 Lingjiang Road, Yuzhong District, Chongqing 400010, PR China
}

pathogenic cells. Additionally, these cytokines are important factors in inflammation and pathophysiology.

In this study, we monitored the effects of UTI and TAX, individually and in combination, on the growth of the negative estrogen receptor (ER-) human breast carcinoma cell line, MDA-MB-231. Using both cultured cells in vitro and xenografted tumors in vivo, we also examined the effects of UTI and TAX on apoptosis and the expression levels of IL-6, IL-8, and TNF- $\alpha$ cytokines.

\section{Materials and methods}

\subsection{Cell lines and animals}

The human breast cancer cell line MDA-MB-231(ER-) was a generous gift from the Shanghai Institutes for Biological Sciences, Chinese Academy of Sciences (CAS). Fifty female BALB/c-nu/nu nude mice, 5 weeks old and weighing 17-21 g, were purchased from the Beijing Institute of Experimental Zoology, CAS, and maintained in the Chongqing Medical University Animal Research Center (production license No. SCXK (Jing), 2005-0014, usage permit No. (Yu), 2007-0001).

\section{Biomed Central}




\subsection{Reagents}

UTI was kindly provided by Techpool Bio-Pharma Co., Ltd. TAX was a generous gift from Sanofi-aventis Pharma Co., Ltd. Maxima ${ }^{\mathrm{TM}}$ SYBR Green/ROX qPCR Master Mix (2X) and RevertAid ${ }^{\mathrm{TM}}$ First Strand cDNA Synthesis Kits was purchased from Fermentas Co. Ltd., Canada; Trizol kit was purchased from Invitrogen Co, Ltd; RT-PCR kit was purchased from NanJing KeyGen Biotech Co, Ltd. MTT ((3-(4,5-dimethylthiazol-2-yl)-2,5diphenyltetrazolium bromide), dimethyl sulfoxide (DMSO), propidium iodide(PI), and phosphate buffered saline (PBS) were purchased from Sigma Chemical Co., Ltd. AMV reverse transcriptase was purchased from Promega Co, Ltd; RPMI-1640 was purchased from GIBCO Co., USA. The secondary antibody kit and diaminobenzidine (DAB) chromogenic substrate were purchased from Zhongshan Goldenbridge Biotechnology Co., Ltd. Vascular endothelial growth factor-C (VEGFC), basic fibroblast growth factor (bFGF), and nerve growth factor (NGF) primary antibodies were purchased from Abcam Co., Ltd., UK.

\subsection{Cell cultures and nude mice}

MDA-MB-231 cells were cultured in RPMI-1640 medium containing $10 \%$ fetal bovine serum (FBS), $100 \mathrm{U} /$ $\mathrm{mL}$ of penicillin, and $100 \mathrm{U} / \mathrm{mL}$ of streptomycin at $37^{\circ} \mathrm{C}$ in a $5 \% \mathrm{CO}_{2}$ atmosphere. Following propagation for $2-3$ days, cells in logarithmic growth phase were digested with $1.0 \mathrm{~mL}$ of $0.25 \%$ trypsin for $2-3 \mathrm{~min}$, separated from trypsin, and incubated with double antibody solution in RPMI-1640 medium containing 10\% FBS. Nude mice were housed in a specific pathogen free (SPF) environment at $22-25^{\circ} \mathrm{C}$ and $50-65 \%$ relative humidity with sterile drinking water, food, and experimental equipment.

\subsection{Experimental groups and drug treatments}

Cultured MDA-MB-231 cells were divided into four random groups: Control (RPMI-1640 medium alone), UTI $(8000 \mathrm{U} / \mathrm{mL})$, TAX $\left(3.7 \mathrm{ug} / \mathrm{mL} ; 5 \times 10^{-6} \mathrm{M}\right)$, and UTI+TAX. MDA-MB-231 cells were harvested, rinsed twice in PBS, resuspended in serum-free RPMI-1640 medium at a density of $2.5 \times 10^{10}$ cells/L, and inoculated into the right axillary breast tissue of nude mice $(0.2 \mathrm{~mL} /$ mouse $\times 50$ mice $)$. At 21 days post-inoculation, 29 mice with tumors $\geq 500 \mathrm{~mm}^{3}$ were divided into four experimental groups: 1) Control (8 mice injected with PBS); 2) UTI (7 mice injected with $8000 \mathrm{U} / \mathrm{mL} \mathrm{UTI}) ; 3$ ) TAX (7 mice injected with $20 \mathrm{mg} / \mathrm{kg}$ TAX); and 4) UTI + TAX (7 mice injected with both UTI and TAX as in groups 2 and 3). All inoculations were i.p. For groups 1 and 2, $0.2 \mathrm{~mL}$ was injected per mouse every day for 20 days. For groups 3 and 4, $20 \mathrm{mg} / \mathrm{kg}$ was injected on days 1,7 , and 14 . After 21 days, the mice were sacrificed for sample preparation. The maximum length (L) and the minimum diameter (D) of each tumor was measured using vernier calipers to calculate the tumor volume $\left(\mathrm{cm}^{3}\right)$. Tumor growth curves were constructed and tumor growth rates were calculated for each experimental group. We validated the synergistic or antagonistic effects of the drugs by calculating the q value using King's formula. Synergistic, additive, or antagonistic effects were determined by $\mathrm{q}>1.15,1.15>\mathrm{q}>0.85$, $\mathrm{q}<0.85$, respectively. The formulas used were: tumor volume $\left(\mathrm{cm}^{3}\right)=(\mathrm{L} 2 \times \mathrm{D}) / 2$; tumor growth inhibition $\operatorname{rate}(\%)=[1-(\mathrm{V} 1-\mathrm{V} 2) /(\mathrm{V} 3-\mathrm{V} 4)] \times 100 \%$, where $\mathrm{V} 1$ and $\mathrm{V} 2$ are the respective starting and ending average tumor volumes in the drug-treated groups and V3 and V4 are the respective starting and ending tumor volumes in the control group; and $\mathrm{q}=\mathrm{Ea}+\mathrm{b} /[(\mathrm{Ea}+\mathrm{Eb})-\mathrm{Ea} \times \mathrm{Eb}]$, where $\mathrm{Ea}, \mathrm{Eb},(\mathrm{Ea}+\mathrm{Eb})$ represent the inhibitory rates of $\mathrm{UTI}$, TAX, and UTI+TAX, respectively (King's formula).

\subsection{Quantitation of cell proliferation using the MTT assay} Cells were seeded into 96-well plates at a density of $4 \times$ $10^{3}$ cells per $200 \mu \mathrm{L}$ per well. The cells were divided into four experimental groups (6 wells/group) as described in 1.4.1 and cultured in RPMI-1640 + 10\% FBS. After 24,48 , and $72 \mathrm{~h}, 20 \mu \mathrm{L}$ of $5 \mathrm{mg} / \mathrm{mL} \mathrm{MTT}$ was added to each well for $4 \mathrm{~h}$. Then $150 \mu \mathrm{L}$ of DMSO was added to each well with shaking for $10 \mathrm{~min}$. The absorbance (A) at $570 \mathrm{~nm}$ was measured using an enzyme-linked immunosorbant assay (ELISA) plate reader to quantitate the inhibitory rate. The experiment was repeated three times. Inhibitory rate $(\%)=$ (1-experimental group $\mathrm{A}_{570}$ /control group $\left.\mathrm{A}_{570}\right) \times 100 \%$

\subsection{MDA-MB-231 cell apoptosis}

Adherent MDA-MB-231 cells were detached from their substrates by digestion with $0.125 \%$ EDTA-free typsin, centrifuged for $5 \mathrm{~min}$, resuspended, and rinsed by centrifugation in PBS at $4^{\circ} \mathrm{C}$. The cell pellet was resuspended in $490 \mu \mathrm{L}$ PBS containing $5 \mu \mathrm{L}$ of FITCAnnexin and $5 \mu \mathrm{L}$ of $250 \mathrm{ug} / \mathrm{mL}$ PI and incubated on ice for $10 \mathrm{~min}$. After two rinses, the cells were analyzed by flow cytometry using a FACS Vantage SE from Becton-Dickinson, USA.

\subsection{Detection of IL-6, IL-8, and TNF- $\alpha$ mRNA transcripts by RT-PCR}

Based on the complete nucleotide sequences of IL-6, IL8 , TNF- $\alpha$, and control gene $\beta$-actin supplied by GenBank, Primer 5.0 software was used by Nanjing Keygen Biotech Co. Ltd. to design and synthesize primers for reverse transcriptase-polymerase chain reaction (RTPCR). The product lengths for IL-6, IL-8, TNF- $\alpha$, and $\beta$-actin were $84,160,108$, and 136 base pairs, respectively. The primer pairs used were: 
IL-6 sense: 5' AAATTCGGTACATCCTCGAC 3', IL-6 anti-sense: 5' CCTCTTTGCTGCTTTCACAC 3', IL-8 sense: 5' TACTCCAAACCTTTCCACCC 3', IL-8 anti-sense: 5' AAAACTTCTCCACAACCCTC 3',

TNF- $\alpha$ sense: 5' GCCTGCTGCACTTTGGAGTG 3', TNF- $\alpha$ anti-sense: 5 ' TCGGGGTTCGAGAAGATGAT 3', $\beta$-actin sense: 5' GCAGAAGGAGATCACAGCCCT 3 ', and $\beta$-actin anti-sense:5' GCTGATCCACATCTGCT GGAA 3'.

The SYBR Green/ROX qPCR master mix was used with initial denaturation at $95^{\circ} \mathrm{C}$ for $5 \mathrm{~min}$ followed by: 45 cycles of denaturation at $94^{\circ} \mathrm{C}$ for $15 \mathrm{~s}$; annealing at $60^{\circ} \mathrm{C}$ for $30 \mathrm{~s}$; and extension at $55^{\circ} \mathrm{C}$ for $1 \mathrm{~min}$, and $1 \mathrm{~min}$ extension at $95^{\circ} \mathrm{C}$. The luminescence signal was measured during the extension process. The transcritical cycle $(\mathrm{Ct})$ was analyzed using the PCR apparatus procedure and copy numbers were calculated from $2^{-\Delta \Delta \mathrm{Ct}}$, the copy number ratio of expanding target genes and the internal control gene ( $\beta$-actin) to determine the mRNA expression levels of the target genes.

\subsection{Detection of IL-6, IL-8, and TNF- $\alpha$ cytokines in xenografted tumors by immunohistochemistry}

Carcinoma tissues were dehydrated using a graded series from 75, through 80 and 95, to $100 \%$ ethanol. Dehydrated samples were completely immersed in wax, cut into $5 \mu \mathrm{m}$ sections, and mounted on 3-triethoxysilylpropylamine (APES)-treated glass. Sections were treated with $50 \mu \mathrm{L}$ non-immune animal serum plus $50 \mu \mathrm{L}$ of a 1:50 dilution of anti-IL- 6 , IL- 8 , and TNF- $\alpha$ antibodies for $10 \mathrm{~min}$. PBS was used as a negative control. Primary antibody incubations were followed by $50 \mu \mathrm{L}$ of biotinlabeled secondary antibody and $50 \mu \mathrm{L}$ of streptavidinperoxidase (SP) solution for $10 \mathrm{~min}$. The sections were rinsed with PBS three times for $3 \mathrm{~min}$ and $100 \mu \mathrm{L}$ of fresh DAB chromogenic substrate solution was added. Sections were examined microscopically for color development for 5-10 min, redyed with hematoxylin (HE), reblued with saturated lithium carbonate, dehydrated with the graded ethanol series (as above), and sealed in neutral gum.

Imaging of all immunohistochemical sections was performed using a Leica microscope electronic imager. The appearance of $\tan$ color or tan particles indicated a positive reaction in the cells. We performed IOD analysis on the sections in each group using Image Pro-plus v6.0 software to compare the differences between the group.

\subsection{Statistical analysis}

All data were analyzed using PASW 18.0 software and represented as $\bar{x} \pm \mathrm{s}$. The variance analysis was adopted for comparisons between groups. $\mathrm{P}<0.05$ was considered to be statistically significant.

\section{Results}

2.1 Effects of UTI and TAX on MDA-MB-231 cell proliferation

Relative to the control group, the growth of MDA-MB231 cells treated with UTI, TAX, and UTI+TAX for $24 \mathrm{~h}$ was significantly inhibited $(\mathrm{P}<0.05$; Table 1$)$. The inhibitory effect increased in a time-dependent manner when the cells were treated for 48 and $72 \mathrm{~h}(\mathrm{P}<0.01$; Table 1). The strongest inhibitory effect was produced by co-treatment with both drugs and the weakest effect occurred with UTI alone (UTI+TAX > TAX > UTI). The differences were statistically significant $(\mathrm{P}<0.01$; Table 1).

2.2 Effects of UTI and TAX on MDA-MB-231 cell apoptosis Compared to the control group (1.00), the level of apoptosis increased to 1.84 for the UTI group, 3.90 for the TAX group, and 6.79 for the UTI+TAX group (Table 2).

\subsection{Expression of IL-6, IL-8, and TNF- $\alpha$ mRNA in MDA-MB-231}

Treatment of MDA-MB-231 cells with both UTI and TAX down-regulated the expression of IL-6, IL-8, and TNF- $\alpha$ transcripts greater than treatment with either UTI or TAX alone $(\mathrm{P}<0.05$; Figure 1, Figure 2, Figure 3$)$.

\subsection{Effects of UTI and TAX on the growth of ed breast tumor xenografts}

One mouse in the control group died on day 13 and one mouse in the UTI group died on day 18 due to consumption and cachexia. The 7 tumors in the control group enlarged in a time-dependent manner, with no spontaneous tumor deflation or regression. For the 6 mice in the UTI group, the volume of their xenografted tumors gradually increased at a rate less than that of the mice in the control group $(\mathrm{P}<0.05)$. For the 7 mice in the TAX group, the volume of their xenografted tumors also gradually decreased relative to the controls. For the 7 mice in the UTI+TAX group, the volume of their tumors decreased with the greatest rate and extent over time $(\mathrm{P}<0.05$; Table 3; Figure 4$)$.

2.5 Effects of UTI and TAX on the expression of IL-6, IL-8, and TNF- $\alpha$ proteins in breast tumor xenografts

Relative to untreated MDA-MB-231 tumor xenografts, the xenografts from mice treated with UTI, TAX, and UTI+TAX showed decreased expression of IL-6 (Figure 5, Figure 6), IL-8 (Figure 7, Figure 8), and TNF- $\alpha$ (Figure 9 Figure 10) proteins. Treatment with UTI+TAX decreased cytokine expression greater than treatment with either UTI or TAX alone $(\mathrm{P}<0.01$; Figures. 5,6,7,8,9,10). 
Table 1 Effects of UTI and TAX on the proliferation of human breast cancer MDA-MB-231 cells in vitro ( $\left.\mathrm{A}_{570}, \bar{x} \pm s\right)$

\begin{tabular}{|c|c|c|c|c|c|c|}
\hline \multirow[b]{2}{*}{ Groups } & \multicolumn{2}{|l|}{$24 h$} & \multicolumn{2}{|l|}{$48 \mathrm{~h}$} & \multicolumn{2}{|l|}{$72 \mathrm{~h}$} \\
\hline & A value $(\bar{x} \pm s)$ & Inhibition rate (\%) & A value $(\bar{x} \pm s)$ & Inhibition rate (\%) & A value $(\bar{x} \pm s)$ & Inhibition rate $(\%$ \\
\hline Control & $1.086 \pm 0.082$ & 0 & $1.366 \pm 0.042$ & 0 & $1.881 \pm 0.106$ & 0 \\
\hline UTI & $1.000 \pm 0.067^{\mathrm{a}}$ & 7.919 & $0.867 \pm 0.102^{\mathrm{a}}$ & 36.530 & $0.631 \pm 0.067^{a}$ & 66.454 \\
\hline TAX & $0.853 \pm 0.051^{a, b}$ & 21.455 & $0.703 \pm 0.043^{\mathrm{a}, \mathrm{b}}$ & 48.536 & $0.440 \pm 0.063^{a, b}$ & 76.608 \\
\hline UTI+TAX & $0.773 \pm 0.041^{a, b, c}$ & 28.821 & $0.590 \pm 0.059^{a, b, c}$ & 56.808 & $0.315 \pm 0.068^{a, b, c}$ & 83.254 \\
\hline
\end{tabular}

a $P<0.05$ for all treatment groups versus control; ${ }^{b} P<0.01$ for TXT and UTI+TAX groups versus UTI group; ${ }^{c} P<0.01$ for UTI+TAX group versus TAX group.

\section{Discussion}

Ulinastatin (UTI) is a serine protease inhibitor (SPI) with extensive inhibitory effects on cell proliferation and extracellular matrix degradation. Consequently, the protection of patients in radiotherapy and chemotherapy becomes an important consideration for researchers. The experiment of Kobayashi [1] showed that UTI inhibited human ovarian cancer and the effect could be related to UTI down-regulation of protein kinase C (PKC), which regulates the methionine/extracellularsignal of the MEK/ERK/c-Jun-dependent signal pathway to collaboratively down-regulate the plasminogen activator urokinase. The application of UTI and etoposide can enhance the inhibition of metastasis in Lewis lung carcinoma (3LL) [2]. Our experiments show that UTI can inhibit the growth of xenografted breast carcinoma tumors with the co-application of both UTI and TAX being most effective.

As one of the core cytokines, interleukin-6 (IL-6), is produced by lymphocytes, mononuclear cells, fibroblasts, vascular endothelial cells, and some cancer cells, primarily in autocrine and paracrine secretions. After secretion, IL- 6 combines with the $\alpha$-subunit of the membranebound IL- 6 receptor (IL-6R) and the $\beta$-subunit of glycoprotein 130 (gp 130) for cell signaling. Goswami [3] used an anti-IL-6 primary antibody to inhibit the proliferation of human glioblastoma multiforme cells, demonstrating that IL-6 has some effect on promoting tumor cell proliferation. Burger [4] also reported that cancer cells and tumor-related macrophages can release high concentrations of IL-6. Hussein [5] showed that highlevels of IL-6 indicate poor prognosis and the concentration of IL-6 in the serum of breast cancer patients is not only elevated, but increases with the clinical stage of

Table 2 Apoptosis of MDA-MB-231 cells treated with different drugs

\begin{tabular}{ccc}
\hline Treatment & Apoptotic rate(\%) & Fold increase \\
\hline Control & $2.52 \pm 0.53$ & 0 \\
UTI & $7.16 \pm 1.59$ & 1.84 \\
TAX & $12.35 \pm 1.88$ & 3.90 \\
UTI+TAX & $19.64 \pm 2.26$ & 6.79 \\
\hline
\end{tabular}

Data expressed as mean \pm sd. Note: $p<0.05$ among different treatments. breast cancer. Sasser [6] found that the growth rate of MCF-7 estrogen-receptor-positive (ER+) breast carcinoma cells doubled in vitro and increased even more in vivo following treatment with recombinant human IL-6. Our results show that UTI inhibits the expression of IL-6.

Interleukin-8 (IL-8) is produced by monocytes, macrophages, T cells, and vascular endothelial cells. UTI enables neutrophil chemotaxis, defluvium, and lyase release. Additionally, UTI can protect against inflammation, promote $\mathrm{T}$ cell chemotaxis, and reinforce the immune response. Heideman [7] suggested that IL-8 promotes leukin chemotaxis into tumors, leading to tumor neovascularization and the acceleration of tumor growth and metastasis. IL-8 enters cells by combining with the chemokine receptor CXCR1, to activate the extracellular ERK2/1 signaling pathway and promote the formation of new microvessels. It has been reported that the expression of IL-8 in breast carcinoma cells is inversely proportional to the level of estrogen receptors (ER). Based on this relationship, decreased expression of ER increases the expression of IL-8, leading to increased tumor deterioration [8]. Our prophase experiment showed that UTI can inhibit the expression of CXCR4 [9], which is produced by stroma derived factor-1. In the present study, UTI and TAX inhibited the expression of IL-8 in xenografted breast tumors in nude mice.

TNF- $\alpha$ is a peptide hormone that affects tumor cell necrosis, inflammation, and the immune response. The effects of TNF- $\alpha$ are widespread and mediated through nearly all of the TNF- $\alpha$ receptors on tumor cells and many other cells. Gong [10] demonstrated that increased TNF- $\alpha$ promotes invasion and metastasis in ductal carcinomas in a scalar fashion. The TNF secreted by tumor-related macrophages can enhance the invasion of tumors by increasing the expression of matrix metalloproteases (MMPs) in breast carcinoma and vascular endothelial growth factor (VEGF) in the c-Jun $\mathrm{N}$-terminal kinase (JNK) and the NF-KB signaling pathways [11]. Also, the inflammatory cells of the tumor microenvironment, consisting primarily of tumor-related macrophages, can secrete TNF- $\alpha$ continuously to promote tumor formation, invasion, and metastasis via activation of protein-1 (AP-1) and the NF-KB pathway [12]. 


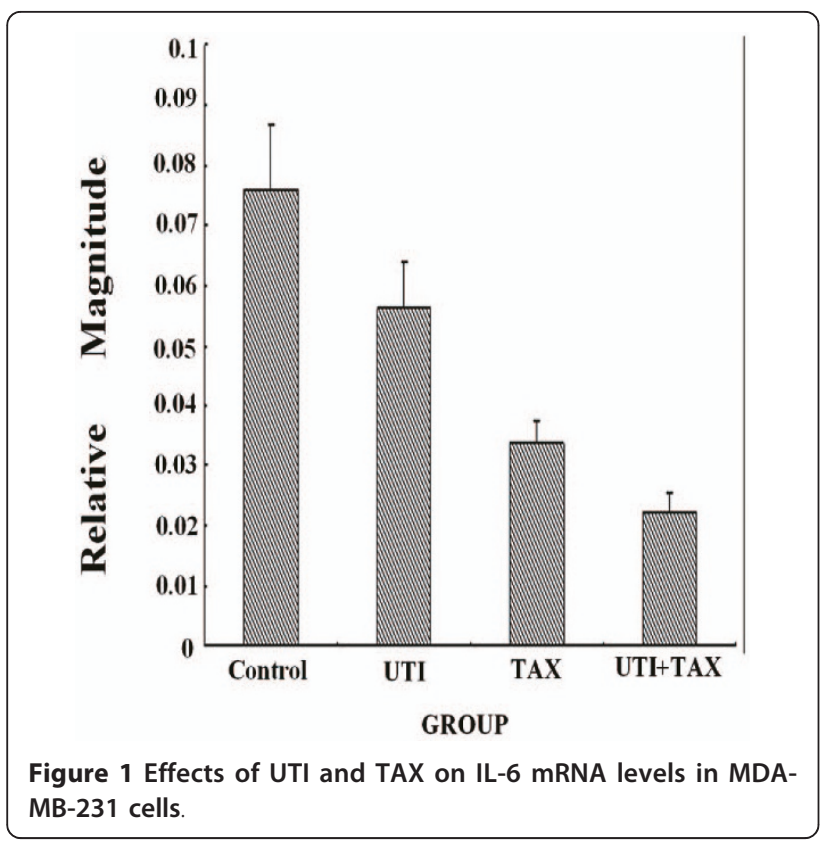

Our in vitro experiments show that UTI can inhibit the proliferation and invasion of MCF-7 human breast carcinoma cells [9] and the growth of MDA-MB-231 (present study). Taken together, these effects could be related to the down-regulation of MMP-9 in breast carcinoma cells by UTI [13]. We show here that both UTI and TAX inhibit the expression of TNF- $\alpha$.

Ulinastatin (UTI) and docataxel (Taxotere, TAX) inhibit the growth of MDA-MB-231 human breast cancer cells cultured in vitro and xenografted into nude mice

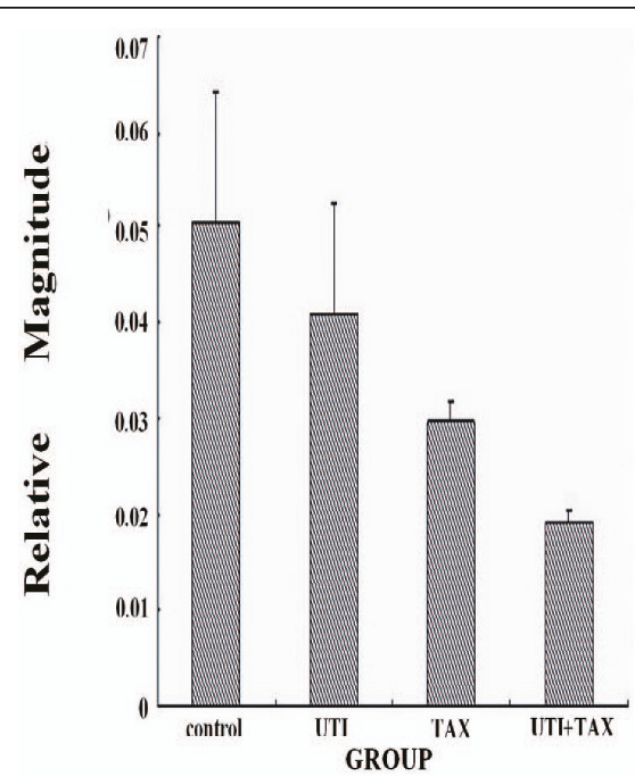

Figure 2 Effects of UTI and TAX on IL-8 mRNA levels in MDAMB-231 cells

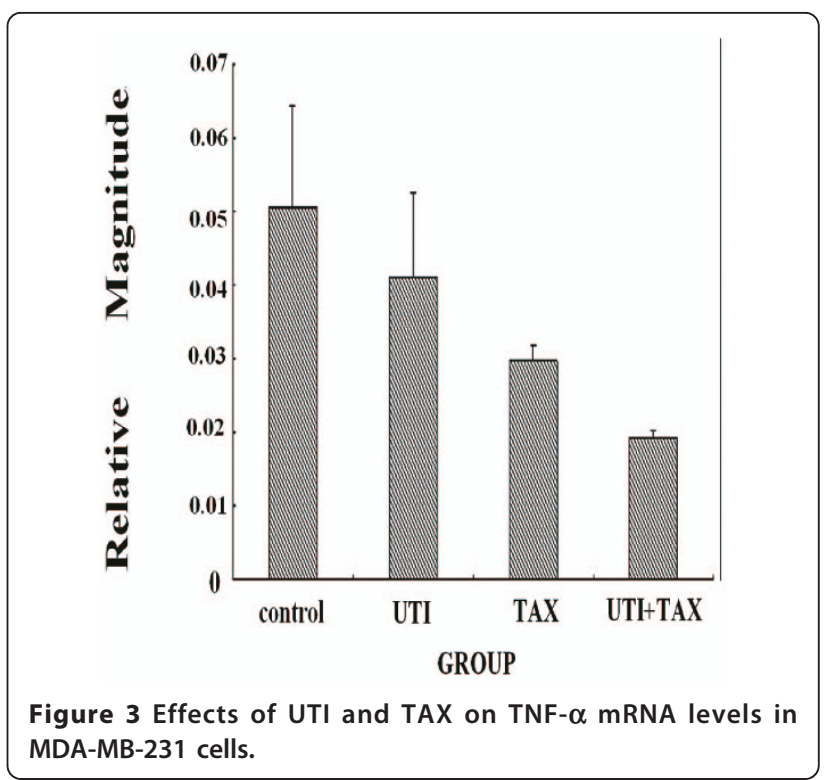

Table 3 Effects of UTI and TAX on the weight and restraining rate of breast tumor xenografts in nude mice

\begin{tabular}{lllll}
\hline Group & $\begin{array}{l}\text { Sample } \\
\text { size(n) }\end{array}$ & $\begin{array}{l}\text { Mean tumour } \\
\text { volume before } \\
\text { treatment }\left(\mathbf{c m}^{\mathbf{3}}\right)\end{array}$ & $\begin{array}{l}\text { Mean tumour } \\
\text { volume after } \\
\text { treatment }\left(\mathbf{c m}^{3}\right)\end{array}$ & $\begin{array}{l}\text { Mean } \\
\text { tumour } \\
\text { inhibition } \\
(\%)\end{array}$ \\
\hline Control & 7 & $0.551 \pm 0.026$ & $4.257 \pm 0.212$ & 0 \\
UTI & 6 & $0.563 \pm 0.012$ & $3.166 \pm 0.134$ & 29.312 \\
TAX & 7 & $0.592 \pm 0.018$ & $1.106 \pm 0.145$ & 86.021 \\
UTI & 7 & $0.589 \pm 0.021$ & $0.627 \pm 0.016$ & 98.264 \\
+ TAX & & & &
\end{tabular}

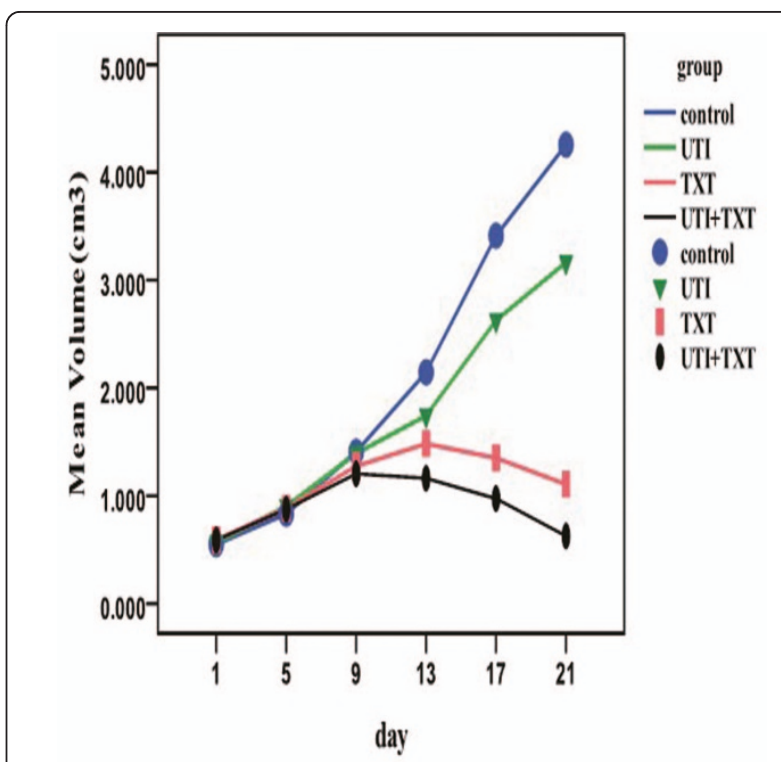

Figure 4 Effects of UTI and TAX on transplanted breast tumor size in nude mice. 


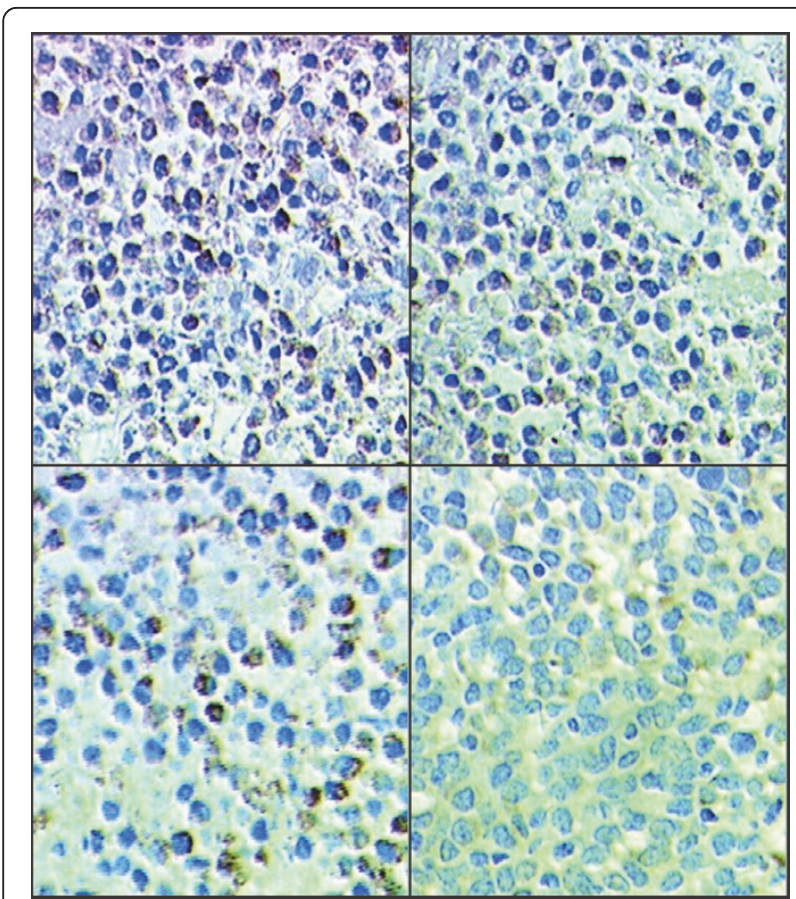

Figure 5 Effects of UTI and TAX on IL- 6 protein expression in human breast cancer xenografts in immunohistochemistry:

1. Control group SP $\times 400$ 2. UTI group SP $\times 400,3$ TAX group SP $\times$ 400 4. UTI+TAX group SP $\times 400$

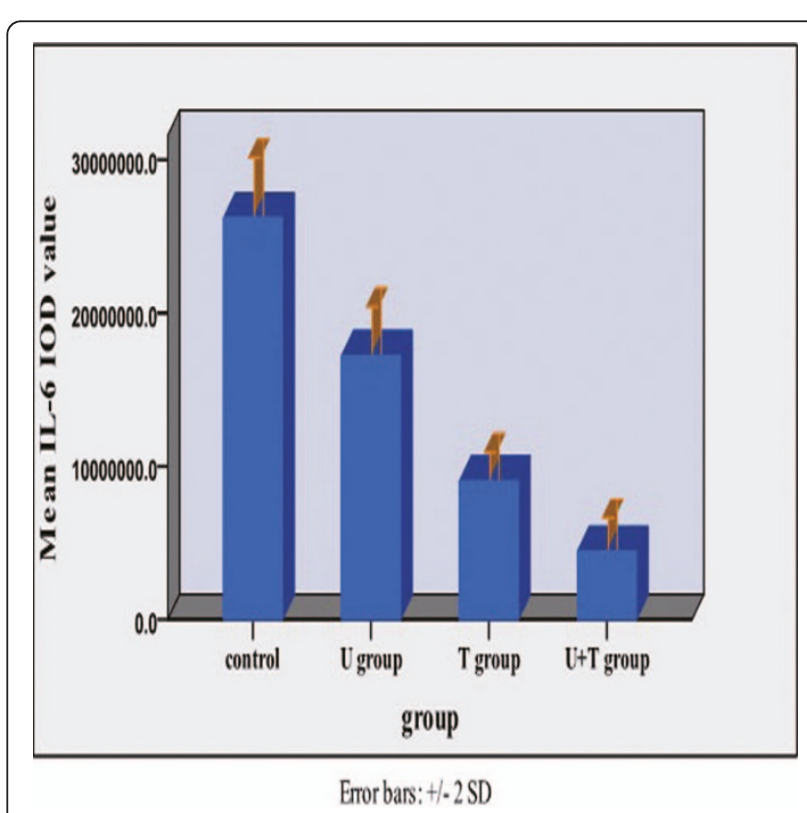

Figure 6 Effects of UTI and TAX on IL- 6 protein expression in human breast cancer xenografts in histogram.

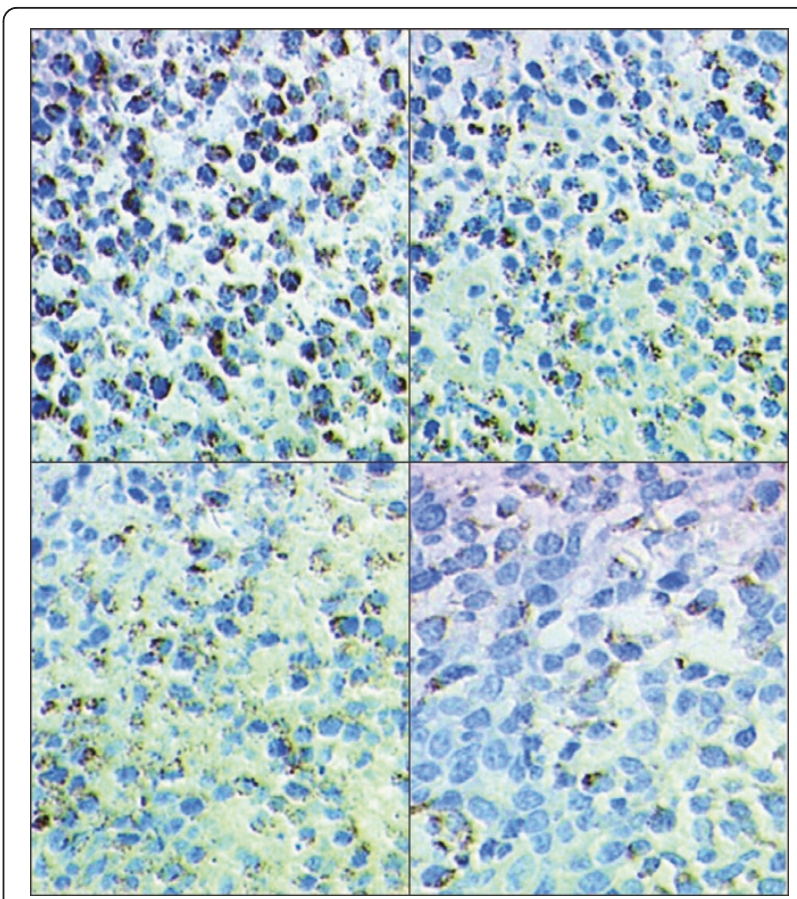

Figure 7 Effects of UTI and TAX on IL-8 protein expression in human breast cancer xenografts in immunohistochemistry: 1 . Control group SP $\times 4002$ 2. UTI group SP $\times 400,3$ TAX group SP $\times$ 400 4. UTI+TAX group SP $\times 400$.

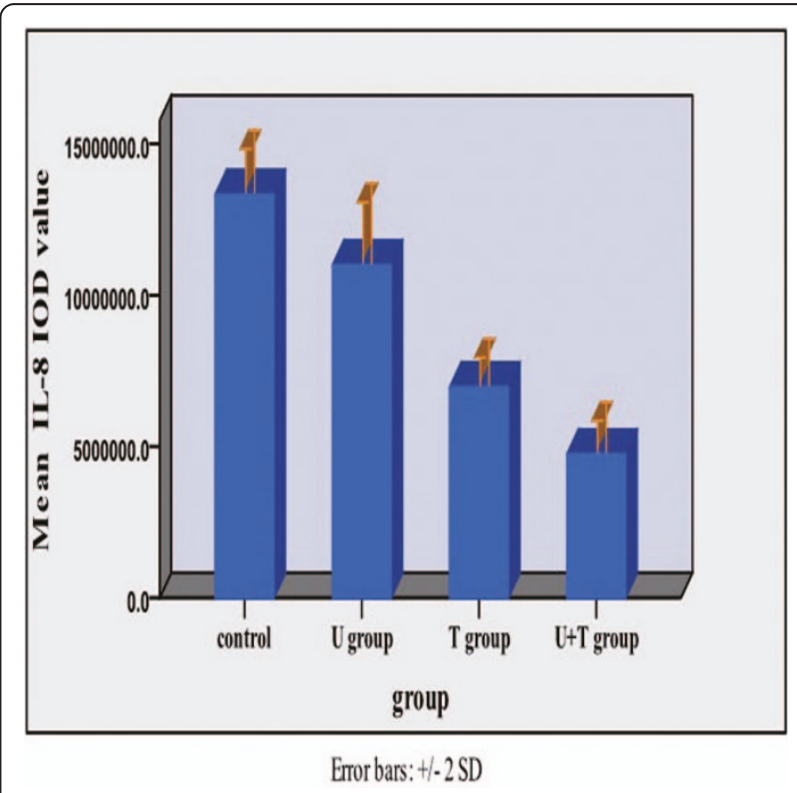

Figure 8 Effects of UTI and TAX on IL-8 protein expression in human breast cancer xenografts in histogram. 


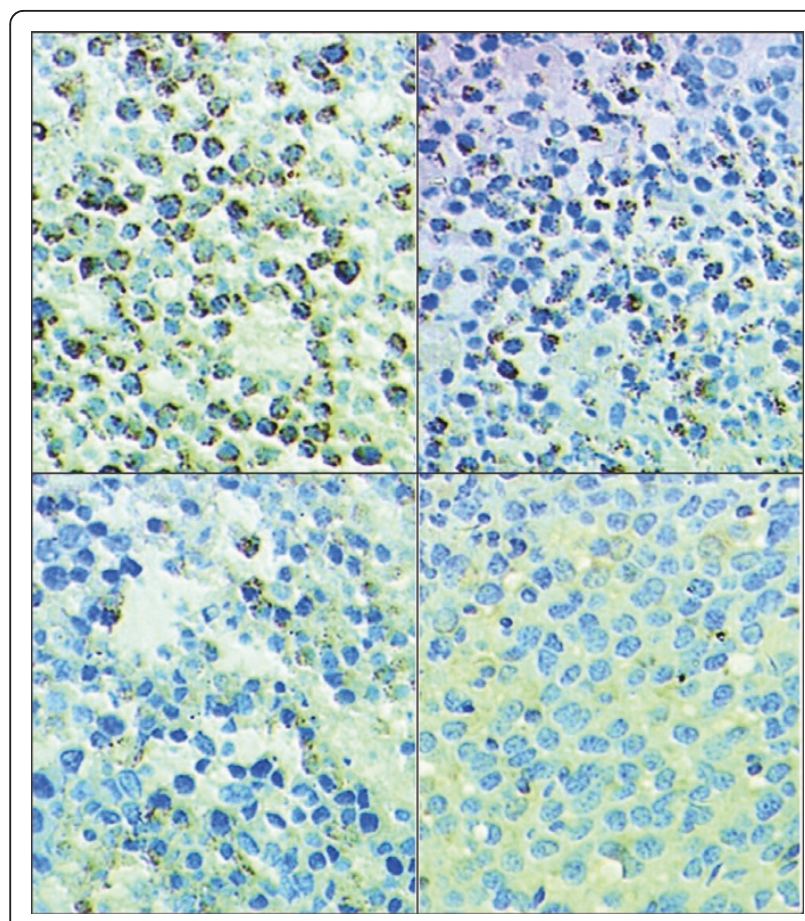

Figure 9 Effects of UTI and TAX on of TNF- $\alpha$ protein expression in human breast cancer xenografts in

immunohistochemistry: 1. Control group SP $\times 4002$ 2. UTI group SP $\times$ 400, 3 TAX group SP $\times 4004$. UTI+TAX group SP $\times 400$.

in vivo. The combination of both drugs is stronger than either drug alone under the conditions tested. The growth inhibition of human breast carcinoma cells and tumors could be related to the concomitant down-

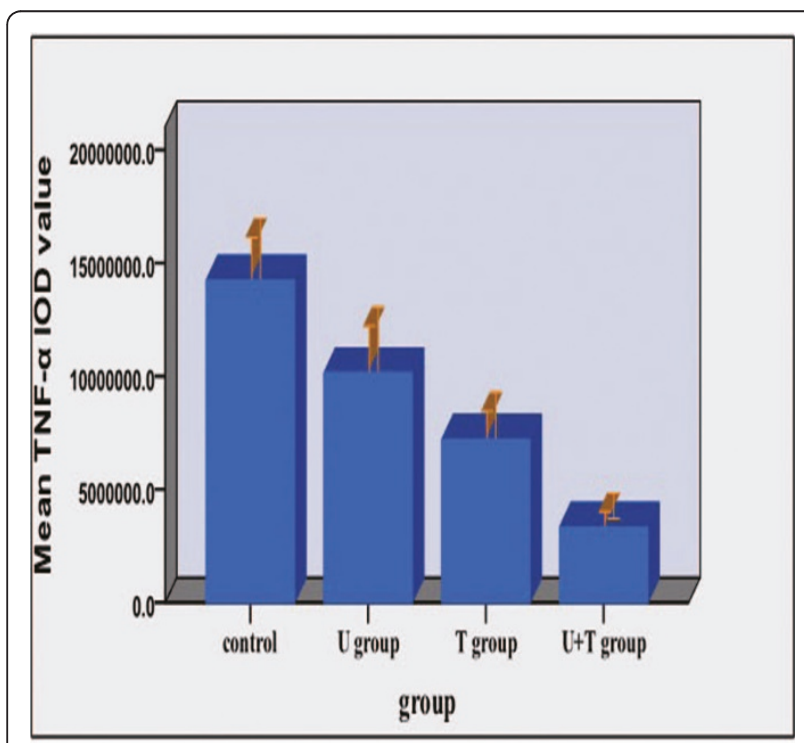

Emor bars: $+1-2 S D$

Figure 10 Effects of UTI and TAX on of TNF- $\alpha$ protein expression in human breast cancer xenografts in histogram. regulation of IL-6, IL-8, and TNF- $\alpha$ in breast carcinoma cells by these drugs.

\section{Acknowledgements}

This work is supported by the Fund of Chongqing Science and Technology Commission(CSCT, 2008AC5082)

\section{Authors' contributions}

XZ did the MTT essay and immunohistochemistry, XS did the Cell-culturing, submitted paper and revised the paper, FG did the medical statistics, $J$ cultured the cell and did PCR, ZS designed this experiment and wrote this paper. All authors read and approved this final draft.

\section{Competing interests}

The authors declare that they have no competing interests.

Received: 5 January 2011 Accepted: 23 February 2011

Published: 23 February 2011

\section{References}

1. Kobayashi H, Suzuki M, Tanaka Y, Hirashima Y, Terao T: Suppression of urokinase expression and invasiveness by urinary trypsin inhibitor is mediated through inhibition of protein kinase C- and MEK/ERK/c-Jundependent signaling pathways. J Biol Chem 2001, 276(3):2015-2022.

2. Kobayashi H, Shinohara H, Gotoh J, Fujie M, Fujishiro S, Terao T: Antimetastatic therapy by urinary trypsin inhibitor in combination with an anti-cancer agent. Br J Cancer 1995, 72(5):1131-1137.

3. Goswami S, Gupta A, Sharma SK: Interleukin-6 mediated autocrine growth promotion in human glioblastoma multiforme cell line U87MG. Neurochem 1998, 71(5):1837-1845.

4. Robert AB, Elizabeth AG, Gene RI, Marc EVE, Minha P, Michael LB, Alberto M, Philip JD, Gale AG, Tetsuya G: Spontaneous release of interleukin-6 by primary cultures of lymphoid and tumor cell populations purified from human ovarian carcinoma. J Interferon Cytokine Res IS 1995, , 3: 255-260.

5. Hussein MZ, Al Fikky A, Abdel Bar I, Attia O: Serum IL-6 and IL-12 levels in breast cancer patients. Egypt I Immunol 2004, 11(2):165-170.

6. Sasser AK, Sullivan NJ, Studebaker AW, Hendey LF, Axel AE, Hall BM: Interleukin-6 is a potent growth factor for ER-a-positive human breast cancer. J FASEB J 2007, 21:3763-3770.

7. Heidemann J, Ogawa H, Dwinell MB, Rafiee P, Maaser C, Gockel HR, Otterson MF, Ota DM, Lugering N, Domschke W, Binion DG: Angiogenic effects of interleukin-8 (CXCL8) in human intestinal microvascular endothelial cells are mediated by CXCR2. J Biol Chem 2003, 278(10):8508-8515.

8. Lin Y, Huang R, Chen L, Li S, Shi Q, Jordan C, Huang RP: Identification of interleukin-8 estrogen receptor-regulated factor involved in breast cancer invasion and angiogenesis by protein arrays. Int J Cancer 2004, 109(4):507-515.

9. Tao Y, Zhijun S: CXCR4 expression in breast cancer and the effects of ulinastatin on its expression level. Chin J Biol 2009, 22:548-551.

10. Gong Y, Sun X, Huo L: Expression of cell adhesion molecules, CIM $4 \mathrm{~s}$ and Ecadherin, and microvessel density in invasive micropapillary carcinoma of the breast. Histopathology 2005, 46(1):24-30.

11. Hagemann T, Wilson J, Kulbe H, Li NF, Leinster DA, Charles K, Klemm F, Pukrop T, Binder C, Balkwill FR: Macrophages induce invasiveness of epithelial cancer cells via NF-KB and JNK. Immunol 2005, 175(2):1197-1205.

12. Szlosarek PW, Balkwill FR: Tumor necrosis factor alpha: a potential target for the therapy of solid tumors. Lancet Oncol 2003, 4(9):565-573.

13. Chen J, Sun Z, Tao Y: Expression and significance of Ulinastatin and cyclophosphamide in breast cancer cell proliferation and invasion and MMP 9 expression. Chin J Biol 2009, 22(9):865-868.

doi:10.1186/1756-9966-30-22

Cite this article as: Zhao et al.: Effects of ulinastatin and docataxel on breast tumor growth and expression of IL-6, IL-8, and TNF- $\alpha$. Journal of Experimental \& Clinical Cancer Research 2011 30:22. 